\title{
PENGARUH MODEL E-LEARNING BERBASIS GROUP INVESTIGATION TERHADAP KETERAMPILAN BERPIKIR KRITIS SISWA DI SMA
}

\author{
Cok Gde Krisparinama1), I Wayan. Santyasa2), Putu Yasa3) \\ 1,2, Universitas Pendidikan Ganesha, Singaraja \\ e-mail: cokgedekrisparinama@gmail.com, santyasa@yahoo.com, putuyasaa@gmail.com
}

\begin{abstract}
Abstrak
Penelitian ini bertujuan menganalisis perbedaan keterampilan berpikir kritis antara siswa yang belajar degan model E-Learning berbasis Group Investigation (ELGI) dan model E-Learning berbasis Direct Intruction (ELDI). Penelitian ini adalah quasi-experiment menggunakan one way pretest-posttest non-equivalent control group design. Populasi sebanyak 6 kelas (215 siswa) kelas XI MIPA SMA Negeri 1 Ubud. Sempel sebanyak 2 kelas (72 siswa) yang ditentukan secara random assignment, sehingga terpilih siswa XI MIPA 1 sebagai kelompok eksperimen dan siswa XI MIPA 6 sebagai kelompok kontrol. Data keterampilan berpikir kritis dikumpulkan dengan 16 butir soal esai dengan materi gelombang bunyi dan cahaya. Analisis data menggunakan analisis deskriptif dan analisis kovarian (ANAKOVA) satu jalur. Keterampilan berpikir kritis siswa yang belajar dengan model ELGI kategori baik secara signifikan lebih tinggi dibandingkan dengan yang belajar dengan model ELDI kategori cukup. Implikasinya, bahwa dalam rangka pencapaian berpikir kritis siswa saat pembelajaran fisika di SMA, mereka sebaiknya difasilitasi dengan model E-Learning berbasis Group investigation.
\end{abstract}

Kata Kunci : e-learning, group investigation, direct instruction, keterampilan berpikir kritis, pembelajaran fisika

Abstract
This study aims to analyze the differences in critical thinking skills between students learning with the E-Learning model based on Group Investigation (ELGI) and the E-Learning model based on Direct Intruction (ELDI). This study was a quasi-experimental study using a one way pretest-posttest nonequivalent control group design. The population was 6 classes (215 students) class XI MIPA SMA Negeri 1 Ubud. Samples of 2 classes (72 students) were determined by random assignment, so that students XI MIPA 1 were selected as the experimental group and XI MIPA 6 students as the control group. Data on critical thinking skills were collected using 16 essay items with sound and light waves as material. Data analysis used descriptive analysis and one-way covariance analysis (ANAKOVA). The critical thinking skills of students who learn with the ELGI model in the good category are significantly higher than those who learn with the ELDI model in the moderate category. The implication is that in order to achieve students' critical thinking when learning physics in high school, they should be facilitated by an E-Learning model based on Group investigation.

Keywords: e-learning, group investigation, direct instruction, critical thinking skills, physics learning

\section{PENDAHULUAN}

Pada abad ke-21 perkembangan ilmu pengetahuan dan teknologi (IPTEK) sangat pesat mengakibatkan persaingan global yang dihdapi sangat tinggi. Sumber daya manusia yang berkualitas diharapkan mampu berkompetisi dimasyarakat luas nantinya. The Partnership for 21st Century Skills (2009) menyatakan ada sejumlah kompetensi atau keterampilan yang harus dimiliki setiap orang pada abad ke-21 yaitu creativity, critical thinking, communication dan collaboration. Oleh karena itu, pemerintah merancang pembelajaran abad ke-21 melalui kurikulum 2013 yang berbasis pada siswa ke dalam pendidikan formal. Keberhasilan pendidikan saat ini tidak berpatok pada hasil yang diperoleh siswa, namun juga kemampuan memecahkan masalah dan keterampilan berpikir siswa. 
Faktanya di lapangan menunjukan kemampuan berpikir kritis siswa masih sangat rendah. Hal ini ditunjukan oleh survei tes Programme for International Student Assessment (PISA) yang dilakukan oleh Organisation for Economic Co-operation and Development (OECD). Pada tahun 2015 Indonesia mengalami peningkatan dengan menempati peringkat ke 62 dari total 70 negara di seluruh dunia. Indonesia memeroleh nilai membaca sebanyak 397, Matematika 386 dan Ilmu Pengetahuan Alam 403 (OECD, 2016). Seiring berjalannya waktu menurut PISA 2018 Indonesia mengalami penurunan dimana menempati peringkat 73 dari 79 negara. Dengan hasil perolehan skor yang dimiliki 371 Membaca, 379 Matematika, dan 396 IImu Pengetahuan Alam (OECD, 2019). Berdasarkan laporan UNESCO dalam Education For All Global Monitoring Report (EFA-GMR), Indeks Pembangunan Pendidikan untuk Semua atau The Education for All Development Index (EDI) tahun 2014 Indonesia berada pada peringkat 57 dari 115. Poin EDI Indonesia adalah 0.935, dibawah Malaysia (0.945) dan Brunei Darussalam (0.965). Rendahnya keterampilan siswa dalam berpikir kritis juga ditunjukkan oleh berbagai fakta empiris dari berbagai penelitian. Penelitian yang pertama dilakukan oleh Santyasa, Kanca, Warpala, dan Sudarma (2019) menyatakan proses pengajaran fisika yang dangkal mengarah pada produk pembelajaran yang kurang optimal, termasuk kesulitan memperoleh keterampilan berpikir kritis. Hal senada juga diungkapkan oleh Budianti \& Purwaningsih (2018) menyatakan bahwa banyak siswa kesulitan memfokuskan diri mereka pada suatu isu permasalahan yang mengakibatkan mereka akan kesulitan dalam membentuk pertanyaan-pertanyaan yang memacu mereka dalam proses berpikir kritis. Dimana menurut Ennis (2016) menyatakan bahwa berpkir kritis merupakan suatu keterampilan berpikir reflektif yang berfokus pada pola pengambilan keputusan tentang apa yang harus dipercaya dan harus dilakukan. Sejalan dengan hasil penelitian Gumilar \& Siliwangi (2019) menyatakan pentingnya kemampuan berpikir mahasiswa dalam proses pembelajaran sangat mempengaruhi perkembangan kognitif, afektif dan pisikomotorik mahasiswa dalam bersikap, mengambil keputusan, dan cara-cara memecahkan masalah baik secara sendiri maupun secara kelompok.

Ketidaksesuaian antara harapan dan kenyataan yang terjadi, dimana pola situasi belajar mengajar di kelas masih berfokus kepada guru atau teacher center. Herlina, Rahayu, dan Wiksya (2019) menjelaskan bahwa pengaplikasian model yang digunakan dalam pembelajaran masih menggunakan model pembelajaran konvensional melalui metode ceramah dan diskusi biasa yang belum membantu mendidik siswa untuk aktif dan membangun keterampilan berpikir kritis. Sejalan dengan pernyataan tersebut menurut Muliana, Muhiddin, \& yunus, (2019) Meski di dalam RPP mengunakan model-model yang inovatif namun dalam penerapan pembelajaran pendidik tetap menggunakan model pembelajaran yang berpusat pada guru. Rendahnya kemampuan berpikir kritis diakibatkan oleh penerapan model pembelajaran berbentuk ceramah, sehingga siswa tidak diberi kesempatan untuk mengembangkan keterampilan berpikir kritis. Model pembelajaran seperti ini menyebabkan siswa sulit untuk mengembangkan keterampilan berpikir kritis yang telah dimiliki oleh masing-masing siswa. Salah satu contoh model pembelajaran yang berpusat pada guru adalah model Direct Intruction. Model pembelajan ini membatasi ruang gerak siswa untuk aktif mengembangkan setiap keterampilannya sesuai indikator pada dimensi keterampilan berpikir kritis aktivitas siswa dikelas hanya mengacu pada intruksi guru.

Salah satu solusi yang efektif dalam mengatasi permasalahan yang terjadi yaitu dengan menerapkan model pembelajaran kooperatif. Pembelajaran Kooperatif adalah 
suatu strategi pembelajaran yang terstruktur dan sistematis, di mana kelompokkelompok kecil bekerja sama untuk mencapai tujuan-tujuan bersama (Santyasa, 2017). Salah satu pembelajaran Kooperatif yang ditawarkan adalah model pembelajaran Kooperatif Group Investigation. Group Investigation (GI) merupakan salah satu model pembelajaran koopertif yang menekankan pada upaya peserta didik dalam kelompok untuk merencanakan kegiatan belajar sendiri untuk memecahkan masalah yang dikasi sesuai dengan sub topik yang dipilih/didapat (Suryani \& Agung, 2012).

Munculnya masalah baru dalam proses belajar-mengajar pada awal tahun 2020 ini yaitu munculnya pandemi Corona Virus Disease (COVID-19), membuat pemerintah harus menerapkan sistem pembelajaran jarak jauh atau pembelajaran daring. Merujuk Surat Edaran No 4 Tahun 2020 Mentri Pendidikan dan Kebudayaan Republik Indonesia terkait pelaksanaan kebijakan pendidikan dalam masa darurat penyebaran Corona Virus Disease (COVID-19), menyatakan bahwa proses pembelajaran dilaksanakan dirumah melalui pembelajaran daring/jarak jauh ini bertujuan memberikan keamanan. Untuk itu dalam proses pembelajaran kali ini akan berbasis pada pembelajaran yang mengutamakan pemanfaatan teknologi sebagai sarana pendukung dalam proses belajar mengajar.

Menurut Santyasa et al. (2019) menyatakan bahwa model pembelajaran Gl sangat cocok untuk bidang studi yang membutuhkan kegiatan studi proyek terintegrasi termasuk pengajaran fisika yang berorientasi pada akuisisi, analisis, dan sintesis informasi dalam upaya menyelesaikan masalah. Dapat disimpulkan bahwa model pembelajaran Kooperatif Group Investigation sangat baik digunakan dalam proses pembelajaran fisika dimana siswa dituntu untuk belajar berkomunikasi dalam kelompok dengan baik untuk menyelesaikan suatu masalah. Keadaan seperti sekarang ini yang menuntut semua proses pembelajaran menjadi pembelajaran jarak jauh yang mengakibatkan model pembelajaran dikombinasikan denga pembelajaran daring. Maka model yang akan diterapkan yaitu model E-Learning berbasis Group investigation dimana dalam penerapannya berfokus pada pembelajaran online namaun langkah-langkah pembelajaran tetap berpatok pada model Group Investigation. Berbeda halnya dengan model Kooperatif Group Investigation yang pada umumnya dilaksanakan secara langsung diterapkan didalam kelas. Model $E$ Learning berbasis Group Investigation dalam penerapannya menggunakan aplikasi Edmodo untuk mendukung pembelajaran jarak jauh ini.

\section{Metode}

Penelitian yang akan dilaksanakan adalah penelitian eksperimen semu atau quasi eksperimental research. Desain penelitian yang digunakan dalam penelitian ini adalah one way pretest-posttest non-equivalent control group design. Penelitian ini menggunakan dua kelompok sampel, yaitu satu kelompok eksperimen dan satu kelompok kontrol.

Populasi dari penelitian ini adalah seluruh kelas XI MIPA SMA Negeri 1 Ubud semester genap tahun ajaran 2019/2020 yang terdiri dari 6 kelas. Sampel dipilih dengan teknik random assignment yang dipilih yaitu sebanyak 2 kelas dari 6 kelas. Semua kelas dalam populasi terdistribusi homogen secara akademik dengan jumlah populasi 215.

Pemelihan sampel dalam penelitian tidak langsung dilakukan pengacakan dalam masing-masing individu, karena individu dalam populasi sudah terdistribusi ke dalam masing-masing kelas. Sampel penelitian terdiri dari dua kelas, yaitu kelas ekperimen 
dan kelas kontrol yang dipilih menggunakan random assignment atau teknik penugasan acak. Kelas eksperimen diberikan model E-Learning berbasis Group Investigation sedangkan untuk kelas kontro yang terdiri dari satu kelas diberikan model E-Learning berbasis Direct Instruction. Berdasarkan undian dalam penelitian ini diperoleh hasil, yaitu XI MIPA 1 ditugaskan sebagai kelas eksperimen dan XI MIPA 6 ditugaskan sebagai kelas kontrol. Jumlah sampel pada penelitian ini sebanyak 72 siswa yaitu $59,67 \%$ dari jumlah populasi siswa.

Instrumen yang digunakan dalam penelitian ini adalah tes keterampilan berpikir kritis untuk mengukur pemahaman siswa terkait materi Gelombang Bunyi dan Gelombang Cahaya. Bentuk tes dikonstruksi berupa tes esai yang terdiri dari 16 butir soal berdasarkan dimensi keterampilan berpikir kritis. Setiap butir soal memiliki rentang skor 0-4. Skor minimal yang dapat diperoleh siswa adalah 0, sedangkan skor maksimal adalah 100.

Penelitian ini menggunakan dua teknik analisis data, yaitu: analis data deskriptif dan analisis data kovarian (ANAKOVA) satu jalur. Analisis dekriptif digunakan untuk menganalisis skor rata-rata dan standar deviasi. Hipotesis yang diajukan diuji dengan analisis kovarian (ANAKOVA). Sebelum melaksanakan uji analisis kovarian harus dilakukan uji asumsi prasyarat yaitu: (1) data bersitribusi normal; (2) varian dalam kelompok yang homogen; dan (3) adanya hubungan linier antara variabel bebas dengan variabel terikat. Tindak lanjut analisis kovarian dalam penelitian ini dilakukan uji signifikansi perbedaan skor rata-rata tes keterampilan berpikir kritis siswa antar kelompok yang menggukan Least Significant Differene (LSD).

\section{Hasil Penelitian Dan Pembahasan}

Deskripsi umum kemampuan berpikir kritis awal sisiwa (pretest) yang dipaparakan mencakup distribusi frekuensi, nilai rata-rata (M), dan standar deviasi (SD) kemampuan berpikir kritis siswa untuk kelompok kelas yang belajar menggunakan model ELGI dan kelompok yang belajar menggunakan model ELDI. Nilai kemapuan berpikir kritis siswa dengan pokok bahasan gelombang bunyi dan cahaya yang terdiri dari 16 butir soal. Berdasarkan hasil data yang dikumpulkan, diperoleh bahwa kemampuan berpikir kritis siswa pada kelompok model ELGI berkisar antara 18,75 sampai dengan 48,44 dan kelompok yang belajar dengan model ELDI berkisar antara 14,06 sampai dengan 51,56 dari skala minimum 0 dan skala maksimum 100 . Nilai ratarata (M) dan standar deviasi (SD) hasil kemampuan berpikir kritis awal siswa (pretest) pada kelompok model ELGI dan kelompok model ELDI untuk setiap unit analisis dengan jumlah unit berturut-turut ( $n_{1}=36$ dan $\left.n_{2}=36\right)$ yaitu

Tabel 1. Nilai Rata-Rata dan Standar Deviasi Kemampuan Berpikir Kritis Awal Siswa

\begin{tabular}{llccl}
\hline Kelas & $\begin{array}{c}\text { Model } \\
\text { :mbelajaran }\end{array}$ & $\begin{array}{c}\text { Nilai } \\
\text { ata-Rata }\end{array}$ & ndar Deviasi & Kualifikasi \\
\hline I MIPA 1 & Model ELGI & 34,42 & 7,30 & angat Kurang \\
I MIPA 6 & Model ELDI & 31,06 & 7,63 & angat Kurang \\
\hline
\end{tabular}

Berdasarkan Tabel 1 diketahui bahwa nilai rata-rata siswa kelompok model ELGI sebesar 34,42 dengan standar deviasi sebesar 7,30, dan kelompok model ELDI sebesar 31,06 dengan standar deviasi sebesar 7,63. Kualifikasi dari kedua model pemebelajaran baik model ELGI dan model ELDI memiliki kwalifikasi sangat kurang. 
Berdasarkan konversi pada pedoman PAP, maka nilai rata-rata pretest pada kedua kelompok berapa pada ketogori yang sama, yaitu sangat kurang.

Kemampuan berpikir kritis siswa pada setiap dimensi dapat diketahui dengan menentukan perbandingan antara lain yang diperoleh siswa pada setiap dimensi dengan jumlah siswa. Nilai rata-rata kemampuan berpikir kritis siswa pada setiap dimensi disajikan pada Gambar 1.

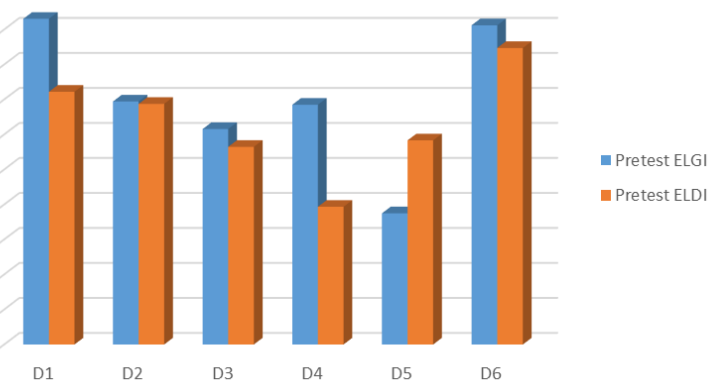

Gambar 1. Grafik nilai Rata-Rata Untuk Masing-Masing Dimensi Kemampuan Berpikir Kritis Awal Siswa Untuk Masing-Masing Kelompok

$\begin{array}{cl}\text { Inan: } & \\ \text { D1 : } & \text { nuskan masalah } \\ \text { D2 : } & \text { ierikan argumen } \\ \text { D3 : } & \text { ukan deduksi } \\ \text { D4 : } & \text { ukan induksi } \\ \text { D5 : } & \text { ukan evaluasi } \\ \text { D6 : } & \text { ituskan dan melaksanakan }\end{array}$

Berdasarkan Gambar 1, tampak bahwa pada kelompok model ELGI nilai rata-rata untuk dimensi kemampuan berpikir kritis lebih besar dari nilai rata-rata pada kelompok model ELDI. Dimensi merumuskan masalah merupakan pencapaian paling tinggi sebesar 46,53 pada kelompok model ELGI, sedangkan dimensi mengajukan argumen merupakan pencapaian paling tinggi sebesar 35,76 pada kelompok model ELDI.

Kemudian berdasarkan hasil data yang terkumpul, diperoleh bahwa keterampilan berpikir kritis siswa setelah perlakuan (posttest) pada kelompok model ELGI berkisar antara 60,94 sampai dengan 95,31, sedangkan kematerampilan berpikir kritis fisika pada kelompok model ELDI berkisar antara 40,62 sampai dengan 78,12 dengan nilai minimum 0 dan maksimum 100. Mean (M) dan standar deviasi (SD) hasil kemampuan berpikir kritis siswa setelah diberikanya perlakuan (posttest) pada kelompok yang belajar dengan model ELGI, dan kelompok yang belajar dengan model ELDI untuk setiap unit analisis dengan jumlah unit berturut-turut $\left(n_{1}=36\right.$ dan $\left.n_{2}=36\right)$ disajikan pada Tabel 3.

Tabel 3. Nilai Rata-Rata, Standar Deviasi setelah Diberikan Perlakuan

\begin{tabular}{lcccc}
\hline Kelas & lel Pembelajaran & $\mathbf{M}$ & SD & Kualifikasi \\
\hline I MIPA 1 & Model GI & 80,03 & 7,62 & Baik \\
I MIPA 6 & Model DI & 63,06 & 8,80 & Cukup \\
\hline
\end{tabular}

Nilai rata-rata setelah diberikan perlakuan siswa kelompok model ELGI sebesar 80,03 dengan standar deviasi 7,62, sedangkan untuk kelompok model ELDI sebesar 63,06 dengan standar deviasi 8,80. Secara umum, nilai rata-rata hasil posttest siswa 
pada kelompok yang belajar menggunakan model ELGl lebih tinggi dibandingkan dengan nilai rata-rata siswa yang belalajar menggunakan model ELDI. Nilai rata-rata kemampuan berpikir kritis siswa setiap dimensi untuk kelompok model ELGI, dan model ELDI disajikan pada Gambar 2.

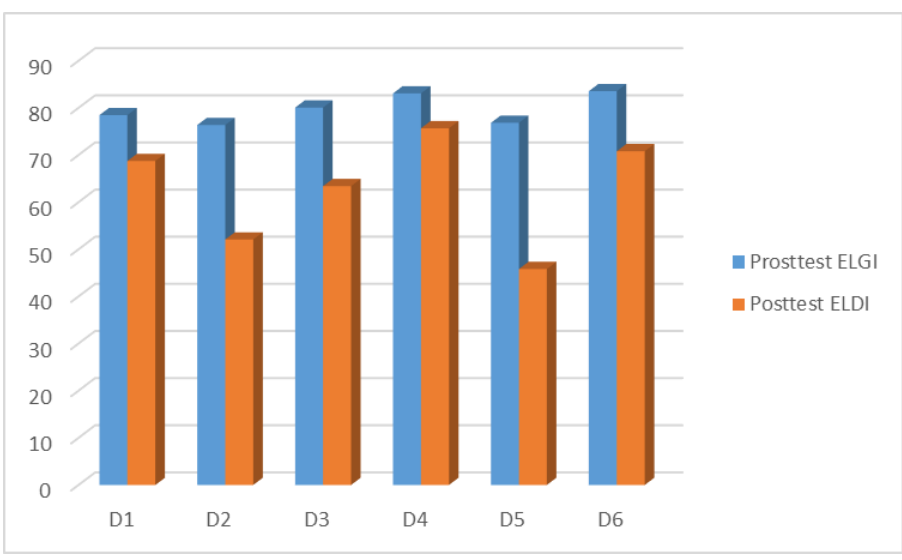

Gambar 2. Grafik nilai Rata-Rata Untuk Masing-Masing Dimensi Kemampuan Berpikir Kritis Siswa Setelah Diberikan Perlakuan Untuk Masing-Masing Kelompok

$\begin{aligned} \text { znan: } & \\ \text { D1 : } & \text { nuskan masalah } \\ \text { D2 : } & \text { ierikan argumen } \\ \text { D3 : } & \text { ukan deduksi } \\ \text { D4 : } & \text { ukan induksi } \\ \text { D5 : } & \text { ukan evaluasi } \\ \text { D6 : } & \text { ituskan dan melaksanakan }\end{aligned}$

Berdasarkan Gambae 2, terlihat bahwa pada kelompok model ELGI nilai rata-rata untuk masing-masing dimensi kemampuan berpikir kritis lebih tinggi dibandingkan dengan nilai rata-rata pada kelompok model ELDI. Dengan nilai rata-rata total untuk kelompok model ELGI adalah 478,47 dan nilai rata-rata total kelompok model ELDI adalah 376,62.

Secara deskriptif, nilai rata-rata kemampuan berpikir kritis siswa setelah diberikanya perlakun dengan menggunakan model ELGI lebih tingggi dibandingkan nilai rata-rata kemampuan berpikir kritis siswa yang mengikuti model ELDI, sehingga dapat dikatakan bahwa kelompok siswa yang menggunakan model ELGI lebih baik dibandingkan dengan kelompok siswa yang mengikuti pembelajaran dengan model ELDI.

Perbandingan anatar model ELGI dan model ELDI dapat dilihat berdasarkan nilai kemampuan berpikir kritis awal siswa yang diperoleh melalui pretest dan nilai kemampuan berpikir kritis siswa setela diberikanya perlakuan yang diperoleh melalui posttest dapat dilihat pada Gambar 3. 


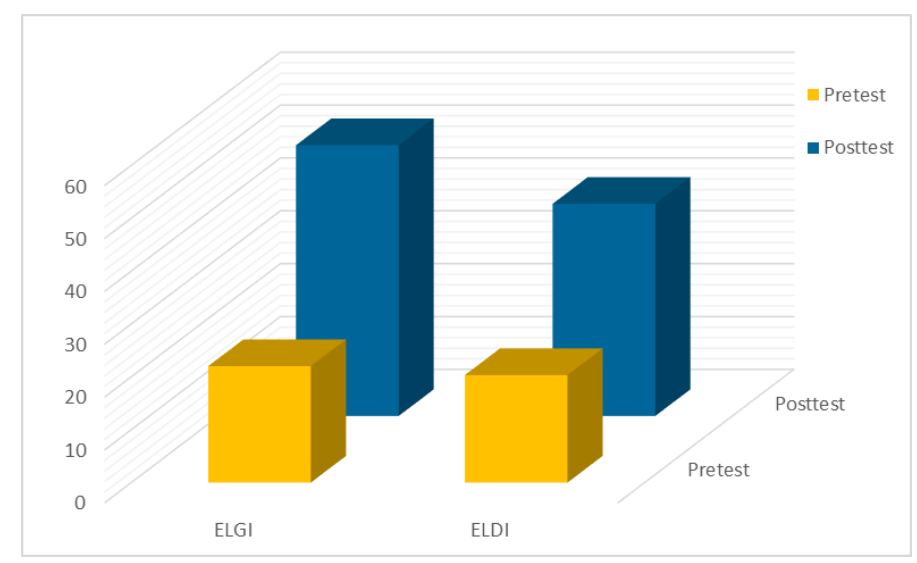

Gambar 3. Perbandingan nilai Pretest dan Posttest untuk Masing-Masing Kelompok

Berdasarkan Gambar 3, dapat dilihat bahwa setiap analisis terjadi peningkatan nilai rata-rata keterampilan berpikir kritis yang diperoleh setiap kelas masing-masing model. Peningkatan hasil nilai rata-rata yang diperoleh oleh masing-masing kelas model ELGI sebesar 80,03 dan model ELDI sebesar 63,06. Hasil ini dapat menunjukan bahwa nilai rata-rata keterampilan berpikir kritis pada kelompok model ELGI lebih tinggi daripada kelompok model ELDI. Maka dapat disimpulkan bahwa terdapat perbedaan nilai rata-rata yang cukup signifikan antara kelompok siswa yang mengikuti pembelajaran dengan menggunakan model ELGI, dan kelompok siswa yang mengikuti pemebelajaran dengan menggunakan model ELDI.

Proses analisis hasil penelitian diawali dengan melakukan beberapa uji asumsi yang harus dipenuhi untuk melakukan analis kovarian (ANAKOVA), dengan menggunakan bantuan SPSS 20.0 for Windows. Uji asumsi yang pertama yaitu uji normalitas sebaran data dilakukan terhadap seluruh data keterampilan berpikir kritis siswa dengan menggunakan statistik Kolmogorov-smirnov. Ringkasan hasil uji normalitas ditunjukkan pada Tabel 5 Berdasarkan data pada hasil yngdiperoleh diketahui bahwa nilai statistik Kolmogorov-Smirnova lebih besar dari 0,05 untuk masing-masing kelompok, maka disimpulkan bahwa data yang diperoleh pada penelitian adalah berdistribusi normal.

Uji asumsi kedua yitu uji homogenitas varian antar kelompok dilakukan dengan menggunakan statistic levene's test of equality of error variance. Ringkasan hasil uji homogenitas ditunjukkan pada Tabel 6 Berdasarkan data pada hasil yangdiperoleh terlihat bahwa hasil uji homogenitas varian antar kelompok terhadap data yang diperoleh menunjukan bahwa nilai-nilai Levene Statistic memiliki angka-angka signifikansi yang lebih besar daripada 0,05. Sehingga dapat disimpulkan bahwa varian data antar kelompok belajar adalah homogen. 
Ringkasan uji asumsi ketiga yaitu uji linieritas dilakukan untuk menunjukkan apakah variabel kovariat dan variabel terikat mempunyai hubungan yang linier atau tidak secara signifikan. Data menunjukkan koefisien arah regresi jika nilai signifikansi dari linearity lebih kecil dari 0,05 dan apabila angka deviation from linearity lebih besar dari 0,05 , pada baris linearity menunjukkan nilai signifikansi 0,003 yang menunjukan lebih kecil dari 0,05 dan pada baris deviation from linearity menunjukkan nilai signifikansi 0,285 yang lebih besar daripada 0,05 . Maka dapat dikatakan hasil diperoleh menunjukan bahwa sebaran data keterampilan berpikir kritis siswa pada masingmasing kelompok adalah linier.

Berdasarkan hasil uji normalitas, uji homogenitas dan uji linieritas keterampilan berpikir kritis siswa, dapat disimpulkan bahwa uji prasyarat analisis untuk pengujian hipotesis ANAKOVA (uji kovarian) satu jalur dapat dipenuhi.

Tabel 8. Ringkasan Hasil ANAKOVA Pengujian Hipotesis

Tests of Between-Subjects Effects

Dependent Variable: POSTTEST
\begin{tabular}{|l|r|r|r|r|r|}
\hline Source & \multicolumn{1}{|c|}{$\begin{array}{c}\text { Type III Sum } \\
\text { of Squares }\end{array}$} & df & Mean Square & \multicolumn{1}{c|}{ F } & \multicolumn{1}{c|}{ Sig. } \\
\hline Corrected Model & $2281.571^{\text {a }}$ & 2 & 1140.785 & 44.115 & .000 \\
Intercept & 5304.161 & 1 & 5304.161 & 205.115 & .000 \\
PRETEST & 158.223 & 1 & 158.223 & 6.119 & .016 \\
KELAS & 1792.892 & 1 & 1792.892 & 69.332 & .000 \\
Error & 1784.304 & 69 & 25.859 & & \\
Total & 155041.000 & 72 & & & \\
Corrected Total & 4065.875 & 71 & & & \\
\hline
\end{tabular}

a. R Squared $=.561$ (Adjusted R Squared $=.548$ )

Berdasarkan ringkasan hasil ANAKOVA yang disajikan pada Tabel 8, dapat dipaparkan sebagai berikut. Pertama, pengaruh keterampilan berpikir kritis awal siswa terhadap variabel dependent dalam penelitian ini yaitu keterampilan berpikir kritis siswa, tampak nilai statistik $\mathrm{F}^{*}=6,119$ dengan angka dignifikansi 0,016. Angka signifikansi tersebut lebih kecil dari 0,05. Hasil ini menunjukkan bahwa terdapat pengaruh signifikan $(p<0,05)$ antara kovariant terhadap keterampilan bepikir kritis siswa. Pengaruh kovariant ini digunakan sebagai kontrol secara statistik dengan menggunakan ANAKOVA, sehingga perbedaan keterampilan berpikir kritis siswa memang benar disebebkan oleh perbedaan perlakuan yang diberikan terhadap masing-masing kelompok.

Kedua, pengaruh variabel bebas (model E-Learning berbasis Group Investigation dan model pembelajaran E-Learning berbasis Direct Intruction) terhadap variabel terikat keterampilan berpikir kritis siswa diperoleh nilai statistik $F^{*}=69,332$ dengan angka signifikansi yaitu 0,001. Angka signifikansi yang diperoleh lebih kecil dari 0,05.

Ketiga, nilai $\mathrm{R}$ squared yang diperoleh berdasarkan hasil analisis adalah 0,561 yang mengindikasikan bahwa besarnya kontribusi model pembelajaran terhadap keterampilan berpikir kritis siswa dalah sebesar $56,1 \%$. Selanjutnya, akan dianalisis signifikansi perbedaan skor rata-rata kemampuan berpikir kritis melalui LSD (Least Significant Difference). Perbedaan skor rata-rata keterampilan berpikir kritis siswa antara kelompok model ELGI dengan ELDI $\Delta \mu=\mu(I)-\mu(J)=10,215$ dengan standar deviasi 1.227 dan angkasignifikansi 0,001. Angka signifikansi lebih kecil dari 0,05, sedangkan nilai $\Delta \mu$ lebih besar dari nilai LSD, dimana nilai LSD yang diperoleh 
berdasarkan perhitungan adalah 2,3904. Hasil ini menunjukan bahwa terdapat perbedaan nilai rata-rata keterampilan berpikir kritis yang signifikan antara kelompok model ELGI dan ELDI. Keterampilan berpikir kritis yang dicapai oleh siswa yang belajar dengan model ELGI lebih tinggi dibandingkan dengan siswa yang belajar dengan model ELDI. Ini menunjukkan bahwa keterampilan berpikir kritis siswa yang dicapai oleh kelompok siswa yang menggunakan model pembelajaran ELGI relatif lebih baik dibandingkan dengan kelompok siswa yang menggunakan model ELDI.

Hasil analisis data deskriptif mendeskripsikan perbedaan skor rata-rata kemampuan keterampilan berpikir kritis awal (pretest) siswa antara kelompok eksperimen (model E-Learning berbasis Group Investigation) dan kelompok kontrol (model E-Learning berbasis Direct Intruction). Data penelitian mengenai skor rata-rata pretest menunjukkan bahwa pemahaman konsep awal siswa dari masing-masing kelompok berada dalam kualifikasi yang sangat rendah.

Kelompok siswa yang menggunakan model ELGl, setelah diberikanya perlakuan (pottest) memiliki skor rata-rata kemampuan berpikir kritis siswa sebesar 80,03 dengan standar defiasi 7,62 yang berkategori baik, sedangkan untuk siswa yang menggunakan model ELDI memperoleh nilai rat-rata sebesar 63,06 dengan standar deviasi sebesar 8,80 yang berkategori cukup. Berdasarkan hal tersebut dapat dilihat perbedaan antara skor rata-rata hasil posttest pada kelompok siswa yang menggunakan model pembelajaran ELGI lebih tinggi dibandingkan dengan model pembelajaran ELDI. Proses pembelajaran yang menuntut kemandirian siswa dalam proses pembelajaran (student center) sangat efektif untuk mengembangkan keterampilan berpikir kritis siswa, hal ini dikarenakan siswa secara mandiri siswa dituntut untuk dapat merumuskan permasalahan, mengajukan argumen, melakukan deduksi, induksi, evaluasi, serta mengambil keputusan dan melaksanakan perencanaan yang telah dibuat sebelumnya. Sejalan dengan hal tersebut Lestari et al (2019) menyatakan bahwa untuk dapat meningkatkan kemamapuan berpikir kritis peserta didik diperlukan adanya inovasi dalam proses pembelajaran sehingga proses pembelajaran berubah dari berpusat pada guru (teacher center) menjadi berpusat pada siswa (students center). Pembelajaran yeng menitikberatkan kepada siswa untuk menemukan dan berperan aktif dalam proses pembelajaran mampu mendukung peningkatan keterampilan berpikir kritis siswa pada proses pembelajaran.

Hasil analisis kovarian pada penelitian ini menunjukkan bahwa terdapat perbedaan keterampilan berpikir kritis antara siswa yang belajar menggunakan model ELGI dengan siswa yang belajar dengan menggunakan model ELDI. Terbukti dari hasil skor statistic $F=69,332$ dengan angka signifikansi 0,001 yang lebih kecil daripada 0,05 . $R$ square hasil perhitungan adalah sebesar 0,548 . Jadi keterampilan berpikir kritis siswa secara signifikan $(p<0,05)$ dipengaruhi oleh pembelajaran yang digunakan. Hal ini menunjukan bahwa model ELGI lebih baik diterapkan dibandingkan dengan model ELDI dalam upaya meningkatkan kemampuan berpikir kritis siswa. Hasil uji LSD menunjukkan bahwa keterampilan berpikir kritis kelompok siswa yang menggunakan ELGI lebih tinggi dibandingkan dengan kelompok siswa yang menggunakan model ELDI yaitu untuk nilai $\mathrm{LSD}=2,3904$ sedangkan $\Delta \mu=\mu(I)-$ $\mu(J)=10,215$. Hasil ini menunjukan bahwa terdapat perbedaan nilai rata-rata keterampilan berpikir kritis yang signifikan antara kelompok model ELGI dan ELDI.

Berdasarkan hasil analisis deskriftif dan analisis kovarian satu jalur, maka dapat dikatakan bahwa model ELGI memberikan pengaruh yang lebih baik jika dibandingkan dengan model ELDI. Terdapat beberapa alasan yang dapat dijadikan dasar penentuan 
bahwa model ELGI lebih baik dalam pencapaian keterampilan berpikir kritis siswa yang maksimal dibandingkan dengan model ELDI yaitu:

Pertama, dilihat dari segi landasan teoritis, model ELGI memberikan pengaruh yang signifikan terhadap peningkatan keterampilan berpikir kritis siswa, hal ini dikarenakan model ELGI memberikan kesempatan kepada siswa untuk belajar secara berkelompok untuk merencanakan kegiatanya sendiri. Tercapainya keterampilan berpikir kritis yang dimiliki oleh masing-masing siswa didukung dengan model ELGI yang digunakan dalam proses pembelajaran, dimana model ini menuntun siswa untuk berperan aktif dalam proses pemebalajaran. Kedua, dilihat dari LKS sebagai perangkat pendukung dalam proses pembelajaran, kelompok siswa yang belajar dengam model ELGI difasilitasi dengan LKS berbasis malah yang bertujuan untuk siswa dapat melatih cara berpikir siswa dalam menyelesaikan suatu keadaan sesuai dengan materi yang dipelajari. Berbeda halnya dengan LKS yang digunakan dalam model ELDI, LKS hanya digunakan untuk melatih kemandirian siswa dalam menjawab soal-soal. Dalam hal ini dapat dilihat bahwa model ELGI lebih unggul dibandingkan model ELDI.

Berdasarkan pemaparan mengenai hasil pembahasan data yang didapatkan dari penelitian ini, terlihat bahwa model ELGI lebih cocok digunakan dibandingkan model ELDI. Meskipun secara garis besar terlihat bahwa model ELGI sedikit lebih unggul dalam meningkatkan keterampilan berpikir kritis siswa dibandingkan dengan model ELDI. Namun terdapat beberapa hal yang menyebabkan masih banyak siswa pada model ELGI maupun model ELDI belum mampu mencapai keterampilan berpikir kritis pada kategori (96-100).

Pertama, siswa belum sepenuhnya mampu menyesuaikan diri dengan model ELGI. Siswa belum mengerti mengenai langkah-langkah kegiatan pembelajaran yang harus dilakukan. Upaya dalam mengatasi kendala yang dialami adalah penulis memberikan motivasi kepada siswa masih merasa canggung dan memeberikan tips dan trik presentasi yang baik. Kedua, hasil yang diperoleh dalam penelitian tidak terlalu pesat perubahanya, ini dikarenakan keterampilan berpikir kritis yang terdiri dari enam dimensi yang harus dibiasakan pada siswa dalam proses pembelajarandi kelas, sehingga hasil yang diperoleh tidak dapat berubah secara derastis dengan waktu yang relatif singkat. Upaya yang dilakukan yaitu tetap melanjutkan menggunakan model ELGI agar secara perlahan siswa dapat menyesuaikan diri. Ketiga, siswa yang notabene sudah terbiasa sebagai peserta pasif mengakibatkan pengerjaan LKS model ELGI yang dilakukan secara kelompok dan menginvestigasi sendiri dimana guru hanya sebagai fasilitator perlunya penyesuaian beberapa kali pertemuan. Adapun upaya yang dilakukan ialah menyampaikan petunjuk pengerjaan dengan baik agar seluruh komponen dalam LKS baik oleh siswa, mengingat siswa belum terbiasa menjawab LKS berbasis masalah. Keempat, keterbatasan dalam letak setiap siswa dalam melaksanakan pembelajaran daring menjadikan beberapa siswa mengeluhkan keterbatasan sinyal, maupun keterbatasan dengan paket data yang boros. Upaya yang perlu dilakukan yaitu diharapkan dari pemerintah mapun sekolah agar bisa mengalokasikan dana untuk pemberian bantuan alokasi dana pembelian paket data untuk kelancaran dalam proses belajar mengajar.

Temuan pada penelitian memiliki implikasi-implikasi sebagai berikut, Pertama, rata-rata keterampilan berpikir kritis siswa yang belajar menggunakan model ELGI memiliki perbedaan dibandingkan dengan siswa yang menggunakan model ELGI. Dengan demikian, penggunaan proses pembelajaran yang tepat sangat berpengaruh terhadap peningkatan keterampilan berpikir kritis siswa. Perbedaan rata-rata keterampilan berpikir kritis siswa disetiap model pembelajaran menunjukkan bahwa, 
rata-rata keterampilan berpikir kritis siswa yang menggunakan model ELGI lebih tinggi dibandingkan dengan menggunakan model ELDI. Kedua, pembelajaran yang menggunakan model ELGI relatif lebih evektif dan tepat untuk diterapkan dibandingkan dengan model ELDI untuk meningkatkan keterampilan berpikir kritis siswa. Model ELGI memberikan kesempatan kepada siswa untuk mengembangkan keterampilan berpikir kritis mereka melalui belajar secara berkelompok untuk menginvestigasi suatu masalah yang diberikan oleh guru. Penerapan model ELGI memberikan melatih siswa untuk belajar untuk merumuskan masalah, memeberikan argument, menemukan pengalaman belajar secara mandiri, hal ini nantinya dapat mempengaruhi keseluruhan dimensi keterampilan berpikir kritis siswa. Hal ini menunjukkan bahwa model ELGI mampu untuk menunjang pembelajaran dengan kurikulum 2013 yang menuntut siswa sebagai fokus utama dalam proses pembelajaran.

\section{SIMPULAN}

Berdasarkan analisis penelitian dan pembahasan dapat dikemukakan bahwa terdapat perbedaan ketrampilan berpikir kritis antara kelompok siswa yang belajar dengan model E-Learning berbasis Group Investigation dan kelompok siswa dengan model E-Learning berbasis Direct Intruction pada proses pembelajaran fisika kelas XI MIPA SMA Negeri 1 Ubud. Dilihat dari hasil penelitin yang diperoleh bahwa keterampilan berpikir kritis siswa yang belajar dengan kelompok model E-Learning berbasis Group Investigation lebih baik diterapkan dibandingkan kelompok model $E$ Learning berbasis Direct Intruction. Nilai rata-rata keterampilan berpikir kritis yang digunakan kelompok siswa yang belajar menggunakan model E-Learning berbasis Group Investigation relatif lebih tinggi dibandingkan dengan kelompok siswa yang belajar menggunakan model E-Learning berbasis Direct Intruction. Maka dapat dinyatakan bahwa model E-Learning berbasis Group Investigation lebih efektif digunakan dibandingkan E-Learning berbasis Direct Intruction dalam proses belajar mengajar. Berdasarkan hasil penelitian yang telah dilakukan, maka dapat diajukan beberapa saran untuk pembelajaran dan penelitian lebih lanjut diantaranya dalam proses penelitian memerlukan waktu yang panjang agar dapat meningkatkan keterampilan berpikir kritis yang optimal. Pelaksanaan proses pembelajaran daring sangat perlu banyak dukungan terutama dari segi fasilitas yang ada salahsatunya paket data yang memadai.

\section{DAFTAR PUSTAKA}

Budianti, Yudi., \& Purwatiningsih, Ani. (2018) Meningkatkan kemampuan berpikir kritis dengan menggunakan model cooperative tipe group investigation pada siswa kelas v sd negeri harapan jaya 1 bekasi utara. PEDAGOGIK, 4(1), 1-8. Tersedia pada: http://jurnal.unismabekasi.ac.id/index.php/pedagogik/article /view /430. Diakses 10 Pebruari 2020

Ennis, R. H. (2016). Critical Thinking Across the Curriculum: A Vision. Tersedia pada: https://link.springer .com/article/10.1007/s11245-016 9401 -4. Diakses 08 Oktober 2019

Gumilar, R. (2019). Peningkatan kemampuan berpikir kritis dengan metode group investigation. JMP Online, 3(12), 1553-1562. Tersedia pada: http://ejurnalmitrapendidikan.com/index.php/e-jmp/article/view/655. Diakses 08 Pebruari 2020 
Herlina, M., Rahayu, I., \& Wiksya, Y. D. (2019). Pengaruh model pembelajaran group investigation (gi) terhadap berpikir kritis dan keterampilan sosial siswa dalam pembelajaran ipa biologi kelas $\mathrm{x}$ sman 2 argamakmur. Jurnal Pendidikan dan Pembelajaran Biologi, 3(2), 142 - 152. Tersedia pada : https://ejournal.unib.ac.id /index.php/jppb/article/view/8724. Diakses 10 Pebruari 2020

Muliana, S., Muhiddin, N. H., \& Yunus, S. R. (2019). Pengaruh model kooperatif tipe group investigation (gi) terhadap keterampilan berpikir kritis peserta didik pada materi pokok sistem ekskresi kelas viii smp negeri 15 makassar. Jurnal Ipa Terpadu, 2(2), 67-74. Tersedia pada: http://ojs.unm.ac.id/index.php/ipaterpadu. Diakses 30 Januari 2020

Santyasa, I. W., Kancab, I. N., Warpala, I. W., \& Sudarma, I. K. (2019) Group investigation and explicit learning models in learning physics at senior high schools. JPPPF: (Jurnal Penelitian dan Pengembangan Pendidikan Fisika), 5(2), 203-206. Tersedia pada: e-Jurnal: http://doi.org/10.21009/1. Diakses 30 Januari 2020

Santyasa, I. W., Kancab, I. N., Warpala, I. W., \& Sudarma, I. K. (2018). The power of group investigation model on student critical thinking, attitude, and character in learning physics. Disajikan dalam Seminar 1st International Conference on Creativity, Innovation, Technology in Education (IC-CITE 2018).

Santyasa, I. W. (2017). Pembelajaran inovatif. Singajara: Undiksha Perss

Suryani, N \& Agung, L. (2012). Strategi Belajar Mengajar. Surakarta: Penerbit Ombak Organisation for Economic Co-operation and Development (OECD). (2014). programme for international student assessment (pisa). Tersedia pada: https://www.oecd.org /pisa/keyfindings/pisa-2012-results-overview.pdf. Diakses 02 Januari 2020

Organisation for Economic Co-operation and Development (OECD). (2016). programme for international student assessment (pisa). Tersedia pada: https://www.oecd.org/ pisa/ PISA-2015-Indonesia.pdf. Diakses 30 Maret 2019

Organisation for Economic Co-operation and Development (OECD).(2019). programme for international student assessment (pisa). Tersedia pada: https://www.oecd.org/ pisa/Combined_Executive_Summaries_PISA_2018.pdf. PISA-2015-Indonesia. pdf . Diakses 02 Januari 2020. 